\title{
The Microbial Role in Hot Spring Silicification
}

Recent experimental studies indicate that microorganisms play a passive role in silicification. The organic functional groups that comprise the outer cell surfaces simply serve as heterogeneous nucleation sites for the adsorption of polymeric and/or colloidal silica, and because different microorganisms have different cell ultrastructural chemistry, species-specific patterns of silicification arise. Despite their templating role, they do not appear to increase the kinetics of silicification, and at the very most, they contribute only marginally to the magnitude of silicification. Instead, silicification is due to the polymerization of silicasupersaturated hydrothermal fluids upon discharge at the surface of the hot spring. Microorganisms do, however, impart an influence on the fabric of the siliceous sinters that form around hot spring vents. Different microorganisms have different growth patterns, that in turn, affect the style of laminations, the primary porosity of the sinter and the distribution of later-stage diagenetic cementation.

\section{INTRODUCTION}

Silica precipitation is an important process in many modern hot spring systems, where venting of hydrothermal fluids leads to the formation of heterogeneously nucleated amorphous silica masses and simultaneously the mineralization, and potential fossilization, of many different types of microorganisms. The waters originating from deep, hot reservoirs, at equilibrium with quartz, commonly contain dissolved silica concentrations significantly higher than the solubility of amorphous silica at $100^{\circ} \mathrm{C}$ (approximately $400 \mathrm{ppm}$ ) (1). Therefore, when these fluids are discharged at the surface, decompressional degassing and boiling, rapid cooling to ambient temperatures, steam loss and evaporation, mixing and changes in solution $\mathrm{pH}$ all work together to cause the solution to suddenly exceed amorphous silica solubility (2). This in turn causes the discharged monomeric silica, $\mathrm{Si}(\mathrm{OH})_{4}$, to polymerize, initially to oligomers (e.g. dimmers, trimers and tetramers), and then to polymeric species with spherical diameters of $1-5 \mathrm{~nm}$, as the silanol groups (-Si-OH-) of each oligomer condense and dehydrate to produce the siloxane (-Si-O-Si-) cores of larger polymers. The polymers quickly grow in size such that a bimodal composition of monomers and particles of colloidal dimensions ( $>5 \mathrm{~nm}$ ) are generated (3). Depending on the degree of supersaturation, these either remain in suspension, due to the external silanol groups exhibiting a residual negative surface charge due to a low zero point of charge (around $\mathrm{pH} 2$ ), they coagulate via cation bridging and nucleate homogenously, or they precipitate heterogeneously on a solid substrate (4). In the latter case, once the first silica monolayer is deposited, silica itself becomes the reactive substrate.

The precipitation of amorphous silica frequently leads to the formation of hard, siliceous sinters. Thick sinters tend to precipitate from neutral to slightly alkaline waters that had reservoir temperatures in excess of $210^{\circ} \mathrm{C}$. Those fluids also had to ascend quickly (i.e. without significant cooling or silica precipitation in the conduit system) with $\mathrm{H}_{2} \mathrm{~S}$ separation and loss of $\mathrm{CO}_{2}$ during boiling and evaporation (2). In contrast, highly acidic effluents (below $\mathrm{pH}$ 3 ) do not form thick sinters because protons appear to inhibit the silica polymerization process (5).

Most siliceous sinters have been constructed, to some degree, around microorganisms. Indeed, even geyserite, the microbanded, amorphous silica sinter that forms in the proximity of spring vents and fissures, where temperatures in excess of $73^{\circ} \mathrm{C}$ were supposedly deemed sterile except for scattered thermophilic microorganisms (6), has now been shown to have surfaces commonly covered with biofilms, while their laminae generally contain silicified microorganisms (e.g. 7-8). Similar findings were also made by Cady and Farmer (9) who showed that thermophilic biofilms contributed to the microstructural development of geyserites by serving as solid substrates for silica precipitation.

When sinters are viewed in detail under the electron microscope, they almost always show microbial cells encrusted in spheroidal grains both extracellularly, on the sheaths or walls of living cells (Fig. 1A), and intracellularly, within the cytoplasm, presumably after the cells have lysed (Fig. 1B). The silicification

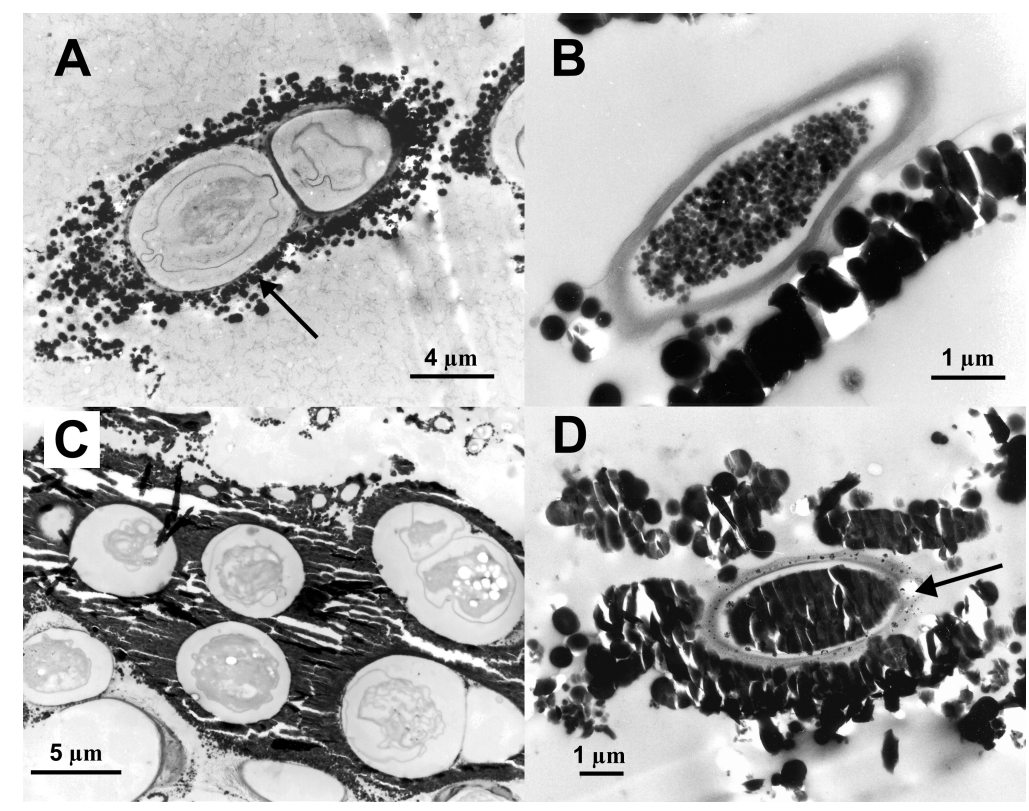

Figure 1. Transmission electron micrographs (TEM) of silicified bacteria from both a geyser outflow channel at Strokkur, Iceland, and a siliceous microstromatolite at Krisuvik, Iceland. (A) Filamentous cyanobacterium (possibly Calothrix sp.) from Krisuvik with epicellular, silica spheroids on outer sheath (arrow). (B) Lysed Chloroflexus sp. cell from Strokkur undergoing intracellular mineralization. (C) Colony of unidentified cyanobacteria from Strokkur that are completely encrusted by silica matrix. Remnants of cytoplasm are still evident inside cell. (D) Lysed cyanobacterium from Krisuvik with epicellular and intracellular silica precipitation. Note selective preservation of cell wall and sheath material (arrow). 
appears to begin with the attachment of silica colloids, on the order of 10's of nanometers in diameter (10-12). Those silica particles then grow in size on the cell surface, and eventually coalesce until the individual precipitates are no longer distinguishable. Frequently, entire colonies are cemented together in a siliceous matrix several micrometers thick (Fig. 1C). In hot spring sinters where diatoms comprise a significant fraction of the biological component (e.g. 13), silicification is biologicallycontrolled, and the processes described herein do not apply.

The timing and rate of silicification relative to death of the microorganisms governs their preservation as intact cells. When silicification is rapid, cell components can rapidly become encased in a silica matrix, thereby retaining intact morphologies. Such a process accounts for the potential fossilization of microbial remains into the rock record (e.g. 14). However, experimental studies have shown that unmineralized cells begin to degrade only a few days after death (15). As a result, their remnants may become progressively obscured, and just a silicified matrix containing sheath and cell wall material may be left of the original organic framework (Fig. 1D). These observations suggest that silicification begins when microbial communities are living, and continues for some time after their death due to the high reactivity of the newly formed silica. This notion is supported by microscopic examination of hot spring sinters where it has been shown that the silica precipitated in the porous spaces between filaments has the same basic spherical colloidal morphology and size as the silica precipitated on the original filaments (e.g. 16).

This paper reviews our current understanding about how microorganisms silicify, and it addresse the key issue of what influence do microorganisms actually have on the construction of hot spring sinters

\section{MICROBIAL SILICIFICATION}

\section{Experimental Studies}

The role that microorganisms play in their own silicification has been the subject of some debate. Some research has suggested that microorganisms play a passive role (17), whereas many other studies suggest that microbial surface ligands (e.g. hydroxy groups) serve as favorable nucleation sites for silica precipitation (e.g. $10-11,18)$. These latter studies suggested that by reducing the activation energy barriers to nucleation, the microorganisms function as reactive interfaces, or templates, for heterogeneous nucleation. Because a sufficient supply of silica is generally available in hot spring effluent, often in excess of 400 ppm $\mathrm{SiO}_{2}$ (e.g. 19), continued adsorption results in the surface sites becoming saturated, allowing particle nucleation to take place. After silica precipitation is initiated upon the bacterial surface, continued growth presumably occurs autocatalytically due to the increased surface area generated by the small silica phases.

Crucially, the silicification of a microorganism does not necessarily result in its death. A study by Phoenix et al. (12) showed that mineralization of the cyanobacterium Calothrix sp. took place exclusively on the outer surface of the sheath (an

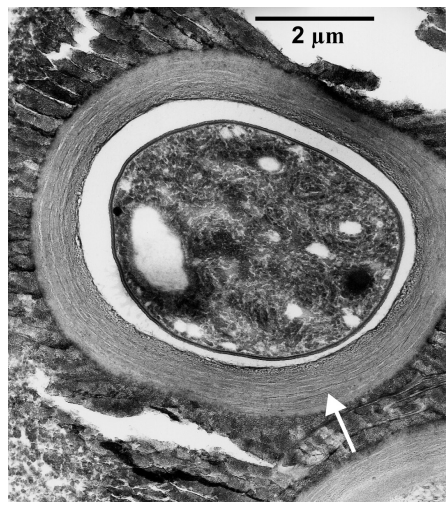

Figure 2. TEM micrograph of a laboratory silicified Calothrix cell (mineralized for 12 days in $300 \mathrm{mg} \mathrm{L}^{-1}$ Si solution) with extensive silicification upon outer surface of sheath (arrow). Note, the excellent intracellular preservation of cytoplasmic material despite the thickness of silica crust. extracellular polysaccharide layer that surrounds the cell). In fact, when Calothrix was grown in silica supersaturated conditions $\left(300 \mathrm{mg} \mathrm{L}^{-1} \mathrm{Si}\right.$ ), its sheath doubled to tripled in width. Concomitantly, the filaments developed extensive mineral crusts up to $5 \mu \mathrm{m}$ thick upon the sheath surface (Fig. 2), yet the cells still fluoresced, they continued to generate oxygen and the mineralized colonies exhibited comparable rates of photosynthesis to the nonmineralized colonies. Furthermore, the cell walls and cytoplasm remained free from silica precipitate. Thus, it appears that some cyanobacteria, such as Calothrix sp., can thrive in silica-rich environments because they form a protective layer that isolates the cells from the potentially damaging effects of silicification.

In the past few decades a number of experimental studies have been designed to elucidate the actual mechanisms by which different microorganisms silicify. Oehler (20) was one of the first to experimentally subject various species of cyanobacteria to colloidal silica solutions over different lengths of time. At temperatures of $\sim 100^{\circ} \mathrm{C}$ several months were required for complete mineralization, while at higher temperatures $\left(165^{\circ} \mathrm{C}\right)$ the cells mineralized quickly, but the filaments fragmented, the trichomes coalesced, intracellular components were destroyed and there was a preferential preservation of the sheath and wall material. Francis et al. (21) experimentally silicified 30 different species of algae, bacteria and fungi for 2 to 24 weeks at temperatures of $55-60^{\circ} \mathrm{C}$ and found that some microorganisms silicified readily, whereas others were less susceptible to silicification. Westall et al. (22) used experiments, similar to those of Francis et al. (21), to show that Gram positive bacteria and eukaryotes silicified with ease, while Gram negative bacteria did not readily silicify. Westall (23) later subjected four bacterial species to highly silicifying solutions and showed that the Gram positive Bacillus laterosporus produced a robust and durable crust after a week of silicification, whereas the Gram negative Pseudomonas fluorescens, $P$. vesicularis and $P$. acidovorans maintained delicately preserved walls that were lightly mineralized. Similarly, Toporski et al. (24) showed that P. fluorescens silicified to a higher extent than Desulfovibrio indonensis after 24 hours in $1000 \mathrm{ppm}$ silica solutions. With increasing levels of silica added, both bacteria suffered significant loss of shape and cellular detail.

Although these studies clearly indicate that silicification is an inevitable outcome of exposing microorganisms to silica supersaturated solutions, they do not resolve whether microorganisms actually mediate, or for that matter, enhance the rates and amounts of silicification. In other words, if microorganisms are indeed passive participants and play a negligible role in the precipitation of silica then their encrustation and/or replacement by amorphous silica should be governed entirely by the

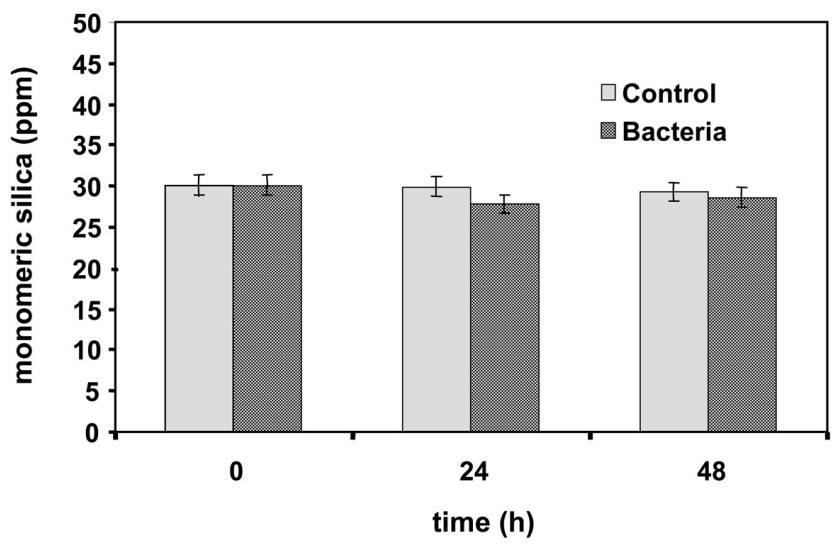

Figure 3. Silica sorption from $30 \mathrm{mg} \mathrm{L}^{-1} \mathrm{Si}$ solution at $\mathrm{pH}$ 7. The grey columns represent the abiotic control and the darker columns represent the bacterial experiment. The error bars represent the analytical uncertainty of the Si measurement. The amount Si sorbed is plotted as concentration of Si remaining in solution. Modified from Yee et al. (26). 
physicochemical conditions of the microenvironment where the microorganism resides. So, it would be expected that in undersaturated silica solutions very little silica would be removed by the biomass, while in silica supersaturated solutions, the amount of silica removed in microbial systems would be comparable to those completely inorganic in nature.

In the first instance, Fein et al. (25) documented that the surfaces of Bacillus subtilis had little affinity for monomeric silica (at concentrations of $<2 \mathrm{mg} \mathrm{L}^{-1}$ ), even at high bacterial densities and under low $\mathrm{pH}$ conditions, where most of the organic functional groups associated with bacterial surfaces are fully protonated and neutrally charged. Using Calothrix sp., Yee et al. (26) also established that in solutions undersaturated with respect to amorphous silica ( $30 \mathrm{mg} \mathrm{L}^{-1} \mathrm{Si}$ solution), interactions between soluble silica and the cell's sheath are insignificant (Fig. 3). These studies directly contradict the earlier premise by Urrutia and Beveridge (27) who suggested that silicate anion adsorption onto positive amino surface functional groups in $B$. subtilis may be responsible for silica accumulation by bacteria. This discrepancy is likely due to $i$ ) there are fewer positively-charged amino groups in the Bacillus wall than negatively-charged carboxyl and phosphoryl groups, leading to the likely repulsion between cell polymers and monosilicic acid (25); and ii) monosilicic acid is not particularly reactive towards organic functional groups (28). However, the Urrutia and Beveridge (27) hypothesis might yet prove to be valid under the conditions where polymeric/colloidal silica reacts with microbial polymers that have abundant amino groups (i.e. if the organic material is protein-rich).

In terms of the kinetics of silicification, early studies with batch systems (supersaturated silica solutions inoculated with cultures of Calothrix) showed that biotic and abiotic experiments resulted in similar amounts of silica precipitation. Importantly, the silicification appeared to occur within the first few hours (Phoenix and Konhauser, unpublished data). Studies have since been undertaken to determine if silica polymerization in silica supersaturated solutions causes the patterns of silicification observed in the laboratory. Yee et al. (26) induced silica polymerization in two ways. First, a stock solution of $\mathrm{Na}_{2} \mathrm{SiO}_{3} \cdot 5 \mathrm{H}_{2}$ was made to $300 \mathrm{mg} \mathrm{L} \mathrm{L}^{-1}$ (Si), it was adjusted from $\mathrm{pH} \sim 12$ to $\mathrm{pH} 7$ with the addition of $\mathrm{HCl}$, and then in some experiments bacteria were immediately added, while others remained bacteria free. The $\mathrm{pH}$ neutralization process caused an immediate increase in the saturation state of the solution and induced silica polymerization. Second, the stock solution was prepared, the $\mathrm{pH}$ was adjusted but then heated for 24 hours at $77^{\circ} \mathrm{C}$ to depolymerize the $300 \mathrm{mg} \mathrm{L}^{-1} \mathrm{Si}$ solution. Afterwards the solution was removed from the oven, and again bacteria were immediately added to some solutions, and the Sibacteria suspension was allowed to cool and polymerize. In both sets of experiments there appeared to be very little difference in the rate of polymerization between bacteria and bacterial-free sys-

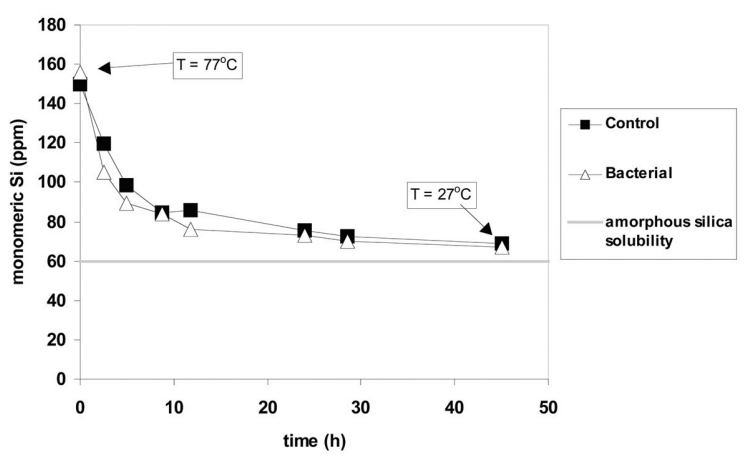

Figure 4. Silica polymerization by cooling. Initial temperature of $77^{\circ} \mathrm{C}$ cooled to $27^{\circ} \mathrm{C}$. The open triangles $(\Delta)$ represent the abiotic control, the solid squares ( $\square$ ) represent the bacterial experiment and the solid grey line indicates the solubility of amorphous silica at $27^{\circ} \mathrm{C}$. Experiments conducted with 155 $\mathrm{mg} \mathrm{L}^{-1} \mathrm{Si}$ solution at $\mathrm{pH}$ 7. Modified from Yee et al. (26). tems. For example, at concentrations of $155 \mathrm{mg} \mathrm{L}^{-1} \mathrm{Si}$, nearly $50 \%$ of the original monomeric silica polymerized in less than 8 hours in both biotic and abiotic experiments (Fig. 4). Benning et al. (29) subsequently showed that in silica-supersaturated solutions, Calothrix sp. only removed $\sim 3 \%$ more $\mathrm{SiO}_{2}$ than bacteria-free systems, but eventually the cells became encrusted in amorphous silica precipitate. Clearly, at high silica levels there is such a strong chemical driving force for silica polymerization, homogeneous nucleation, and ultimately silica precipitation, that there is no obvious need for microbial catalysis.

\section{Cell Surface Influences}

Although microbial silicification at hot springs is incidental, an inevitable consequence of microorganisms growing in polymerizing solutions where silica abounds, both experimental and field studies have shown that different microorganisms are capable of being silicified with different degrees of fidelity. This species-specific pattern is not surprising considering that the actual mechanisms of silicification rely, in part, on the microorganisms providing reactive surface ligands that adsorb silica from solution, and accordingly, reduce the activation energy barriers to heterogeneous nucleation. This means that cell surface charge may have a fundamental control on the initial silicification process.

In an early attempt to describe the mechanisms of silicification, Leo and Barghoorn (30) suggested that monomeric or low molecular weight polymeric silica was bound to the bacterial surface through hydrogen bonding as shown in the equation below.

$$
\mathrm{B}-\mathrm{OH}+\mathrm{Si}(\mathrm{OH})_{4} \rightarrow \mathrm{B}-\mathrm{O}-\mathrm{Si}(\mathrm{OH})_{3}+\mathrm{H}_{2} \mathrm{O}
$$

where $\mathrm{B}-\mathrm{OH}$ represents a hydroxy group on the bacterial surface. Heaney and Yates (28) also suggested silica bound to the bacterial surface through hydrogen bonding, although their study indicated that it was the polymeric/colloidal fraction, not monomeric silica, that was immobilized. The latter hypothesis appears best corroborated by electron microscopic observations of microbial silicification, where the mineralization process appears to begin with the immobilization of preformed silica colloids onto the cell's surface (10-12).

Recently, Phoenix et al. (31) showed that the sheath of Calothrix is electrically neutral at $\mathrm{pH} \mathrm{7,} \mathrm{consisting} \mathrm{predominantly} \mathrm{of}$ neutral sugars, along with smaller amounts of negatively-charged carboxyl groups and positively-charged amino groups, in approximately equal proportions. On the one hand, the low reactivity of Calothrix's sheath gives its surface hydrophobic characteristics that facilitate their attachment to solid submerged substrates, i.e. siliceous sinters. On the other hand, the sheath's electroneutrality makes it less repulsive towards the polymeric silica fraction in solution, and hence, it may actually aid in the silicification process.

To test if the carbohydrates do indeed play a critical role in Calothrix silicification, Benning et al. (29) used high resolution synchrotron radiation Fourier-transform infra-red (SR-FTIR) to follow the silicification of individual filaments. Their results recorded an increase in the integrated area of the absorbance spectra for the silica/polysaccharide region $\left(\mathrm{Si}-\mathrm{O} / \mathrm{C}-\mathrm{O} ; 1150-950 \mathrm{~cm}^{-1}\right)$, followed later by the occurrence and growth of a $\mathrm{Si}-\mathrm{O}$ band at $800 \mathrm{~cm}^{-1}$. From this, a two-step process was determined, where in the first stage the polysaccharide sheath thickens (in response to incubation in a silica-supersaturated medium), followed by the abiotic accumulation of amorphous silica precipitates upon the cell surface through the condensation of silanol groups.

In contrast to Calothrix, the highly anionic nature of Bacillus subtilis may limit silicification from occurring on its cell wall as a result of electrostatic charge repulsion between the organic ligands and the negatively-charged silica species. For such anionically-charged cell wall surfaces, silicification necessitates 
some form of cation bridging (e.g. $\mathrm{Fe}^{3+}, \mathrm{Al}^{3+}$ ). Numerous studies have demonstrated a strong interaction between aqueous cationic $\mathrm{Fe}\left[\right.$ e.g. $\left.\mathrm{Fe}(\mathrm{OH})^{2+} ; \mathrm{Fe}(\mathrm{OH})_{2}^{+} ; \mathrm{Fe}^{3+}\right]$ and $\mathrm{Al}\left[\right.$ e.g. $(\mathrm{AlLOH})^{+}$, where $\mathrm{L}$ is an organic ligand] species and the organic ligands that comprise the cell surface (e.g. 32, 33). Not surprisingly, Fein et al. (25) showed that bacteria pre-coated with Fe(III) and $\mathrm{Al}$ (III) hydroxides could act as templates for silica deposition (in undersaturated solutions) over a wide range of $\mathrm{pH}$ conditions. Compared to the negligible silica adsorption directly onto the cell surfaces in undersaturated solutions, virtually all of the monomeric silica was removed from solution by the presence of either Fe or Al. Moreover, increasing the concentrations of $\mathrm{Fe}$ or $\mathrm{Al}$ increased the extent of silica adsorption over the entire concentration range studied.

Similar to above, Phoenix et al. (34) measured the effects of iron bridging in mixed Fe-Si solutions. However, the solutions used were supersaturated with respect to amorphous silica and the cells were not pre-coated with iron. Their results demonstrate that Bacillus subtilis cells immobilize more Fe than bacterialfree systems in solutions with iron concentrations $<50 \mathrm{ppm} \mathrm{Fe}$, yet as iron concentrations increase, the difference between iron immobilization in bacterial and bacteria-free systems decrease as abiotic precipitation processes become increasingly dominant (Fig. 5A). Correspondingly, the bacterial and bacteria-free systems remove nearly identical amounts of silica from solution, whatever the iron concentration, again due to the dominance of abiotic precipitation processes (Fig. 5B). These results suggest

(a)

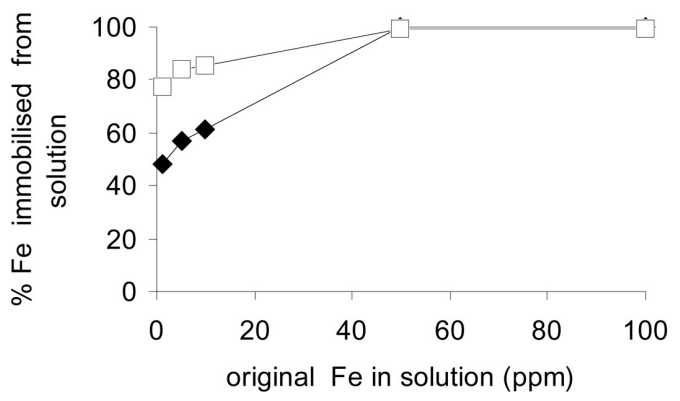

(b)

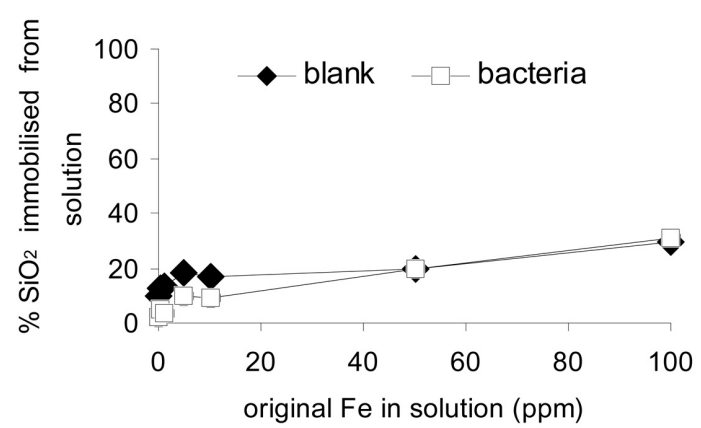

Figure 5. Percent of Fe or $\mathrm{SiO}_{2}$ immobilized onto Bacillus subtilis or microcosm wall from a $400 \mathrm{mg} \mathrm{L}^{-1} \mathrm{SiO}_{2}$ solution as a function of original Fe concentration. (A) Percent Fe immobilized after 4 hours. (B) Percent $\mathrm{SiO}_{2}$ immobilized after 4 hours. Modified from Phoenix et al. (34).

that in natural hot spring systems, where the concentration of soluble silica far exceeds that of iron, not only will the amount of iron partitioned onto the microbial mats be insignificant compared to the abiotic reactions of silica with $\mathrm{Fe}(\mathrm{OH})_{3}$ or various clay phases, but the vast majority of silica precipitated will occur without the aid of a cation bridge.

Collectively, these results imply that the association between silica and anionically-charged cell wall material is not caused by direct silica-bacteria interactions, but rather it is caused by the adsorption of silica onto $\mathrm{Fe}$ and $\mathrm{Al}$ oxides (and likely other multivalent metal cations) that are electrostatically bound to the bacterial surface. Consequently, silicate biomineralization onto negatively-charged bacteria appears to be a two stage process, whereby a metal cation binds initially to the cell wall, that in turn inorganically reacts with dissolved silica (35). Such a scenario has direct analogues with the partitioning of negativelycharged silica colloids onto positively-charged Fe(III) oxides. At circumneutral $\mathrm{pH}$, two surface species of iron oxide exist, namely $\mathrm{FeOH}_{2}^{+}$and $\mathrm{Fe}(\mathrm{OH})^{0}$. In either case, modelling suggests the Fe-silicate minerals form via hydrogen bonding between the hydroxyl ions associated with both the solid-phase iron and the polymeric silica (e.g. 36, 37).

In summary, microorganisms do not notably increase the kinetics or amount of silica precipitation in hot spring systems. The microbial surface only interacts with reactive silica or metal species in the initial stages of silica immobilization; once the organic polymers are saturated with the silica complex, then the precipitate grows abiotically. Even so, the initial phase of bacterial silica immobilization appears to occur via two distinct mechanisms: $i$ ) hydrogen bonding between hydroxyl ions in the silica polymer with hydroxy groups in neutrally charged cyanobacterial sheaths; and ii) metal cation-(hydr)oxide bridging between the silica and the negatively-charged cell wall functional groups. A third mechanism, the reaction between polymeric/colloidal silica and positively-charged amino groups has yet to be conclusively demonstrated. Irrespective of which process takes place, given continuous exposure to silica supersaturated solutions, one would expect that all microorganisms in a hot spring will inevitably end up with similar styles of silicification because once the initial silica is bound, additional silicification becomes a strictly inorganic process. Not surprisingly, Jones et al. (38) have shown that each of the microbial species (growing on a glass slide submerged for four days in a $440 \mathrm{mg} \mathrm{L}^{-1} \mathrm{SiO}_{2}$ solution) at Iodine Pool, located in the Waimangu geothermal area on the North Island of New Zealand, lost any key identifiable features that allowed for their recognition. In other words, so much silica was deposited on these cells that it was no longer discernible as to what comprised the initial silica-microbe interaction.

\section{SINTER FORMATION}

Individual sinter deposits are architecturally complex because the intricate lateral and vertical intercalations of lithofacies and biofacies (i.e. geyserite, spicules, columnar and stratiform microstromatolites, oncoids, and coccoid microbial mats) are common at all scales. Each biofacies may be characterized by a unique microbial assemblage that developed in response to the operative hydrodynamic, geochemical and temperature regimes (e.g. 39, 40). In turn, these microorganisms exert significant control and influence on fabric development in the sinters.

Most sinters found in geyser and hot-spring systems are formed of amorphous silica, accessory minerals (e.g. kaolinite, sulfur, jarosite, gypsum, halite), lithological detritus and biological material (41). Calcium carbonate (calcite and aragonite) and iron hydroxides also form in association with sinter deposits, but those minerals generally are not conducive to cell preservation (42).

Not all amorphous silica found in these deposits originated through the same process. As a result, there is significant textural variation in the sinters that can be attributed to the balance between the silica that encrusted microorganisms (as described above), the silica that replaced organic substrates (e.g. sheaths and cell walls of microorganisms) and other organic surfaces (e.g. wood, leaves), and the isopachous cements that lined and/or filled pores and cavities in the sinters (Fig. 6A). The amorphous silica that encrusts a microorganism is really a cement that is precipitat- 


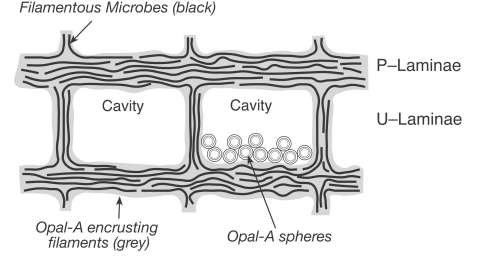

B
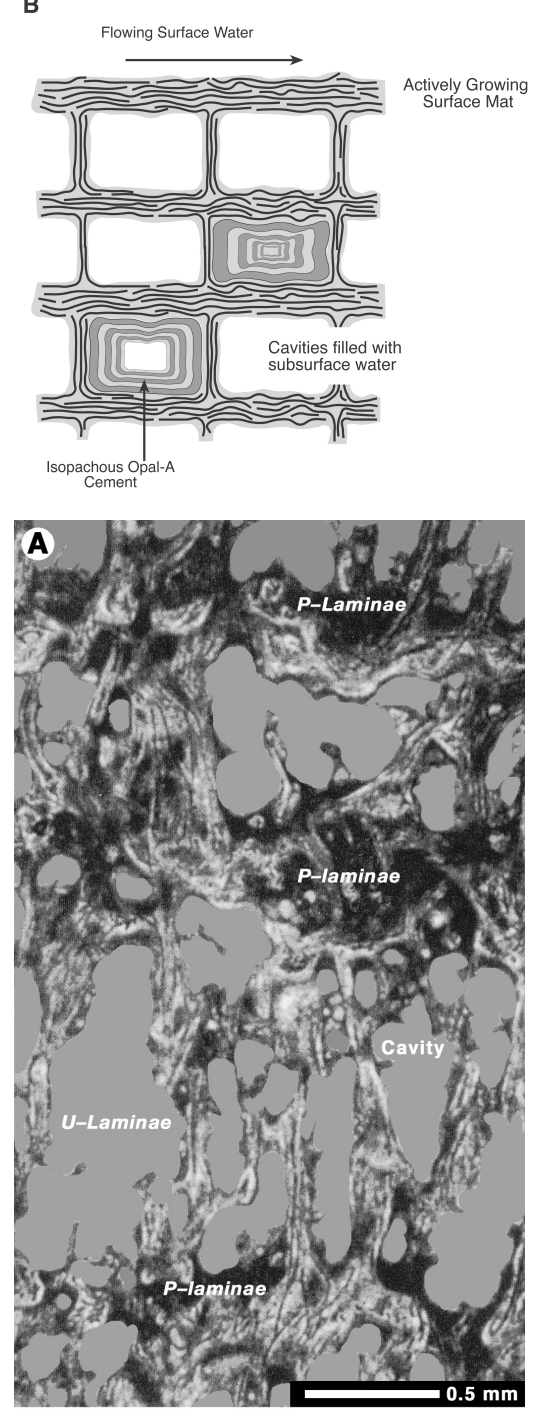

Figure 7. Stratiform stromatolite formed of $\mathrm{P}-\mathrm{U}$ couplets, distal part of discharge apron at Ohaaki Pool, North Island, New Zealand. (A) General view of stromatolite showing cavities preferentially located in the laminae formed of upright filaments. (B) Change in growth attitude of filamentous microorganisms (arrow) at transition from P-laminae to U-laminae.

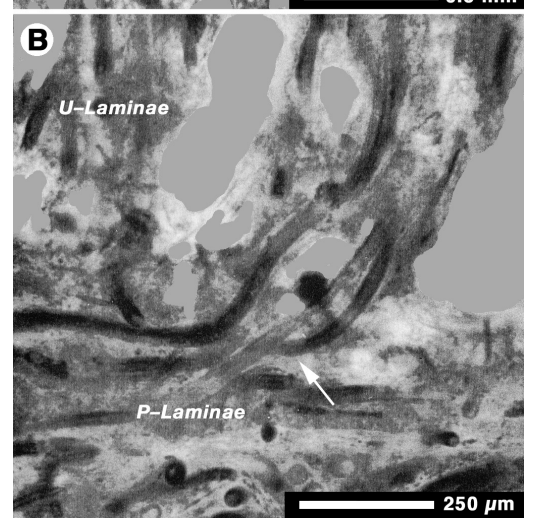

ed from pore fluids in the same manner as the isopachous cement. Herein, encrustation is used to denote an amorphous silica cement that coats the surfaces of individual microorganisms. Isopachous cements line and fill cavities of any type. As a consequence, the shape of the isopachous cement areas reflect the shape of the original cavity, not the shape of individual microorganisms. In addition, discrete silica spheres also accumulate in small, protected pockets (41). The encrustation and replacement of organic materials and the precipitation of the amorphous silica spheres usually takes place while the sinter is on or very close to the surface of the discharge apron. Spring waters that are flowing over the surface of the discharge apron usually mediate the precipitation of amorphous silica in this setting. In contrast, precipitation of the isopachous cements is mediated by subsurface water flow through the older, buried parts of the sinter (Fig. 6B). The porosity and permeability of the original sinters are the most important factors that control the distribution of the cements simply because they govern the passage of the subsurface waters.

Much of the textural variation in siliceous sinters can be attributed to the different types of microorganisms that inhabit different discharge aprons or different parts of an individual apron, primarily in response to differences in water temperature and acidity. Areas covered by alkaline water that have temperatures in the $20-$ $40^{\circ} \mathrm{C}$ range are commonly colonized by Calothrix - a filamentous cyanobacteria that is liable to extensive early silicification (e.g. 43-46). Conversely, fungi that dominate areas with acidic waters ( $\mathrm{pH}$ of $<\sim 5.0$ ), do not seem to be as susceptible to silicification (47). Thus, unlike Calothrix they do not have the same impact on fabric development in their sinters. Elsewhere, more subtle variations in water chemistry seem to control the distribution of different taxa. Fischerella, for example, appears to be restricted to waters that contain little or no sulphur (e.g. 48). Clearly there are many more such examples of microbial niches in hot spring settings (49), and hence, it should not be surprising that variations in microbial populations are commonly manifested in the textures of the sinters simply because different microorganisms interact uniquely with the polymerizing silica solutions.

Most sinters found around geyser and hot-spring vents, and their associated discharge aprons, are characterized by laminations that reflect differences in such features as the type of mineralization, their porosity, the type of microorganisms that they contain, the attitude of those microorganisms and perhaps the complete absence of microorganisms (e.g. 46, 50-53). These features are interrelated because the primary porosity of a sinter is fundamentally controlled by the microbial community and, in particular, the distribution and attitude of the microorganisms in the mats. This can be best illustrated by considering stratiform stromatolitic sinters (16), a common biofacies found on a number of hot spring discharge aprons.

\section{Stratiform Stromatolite Fabrics}

This distinctive sinter is formed of alternating laminae that are dominated by prone filamentous microorganisms (P-laminae), up to $2 \mathrm{~mm}$ thick, and laminae formed of upright filamentous microorganisms (U-laminae), that are up to $5 \mathrm{~mm}$ thick (see Fig. 6 in reference 16). P-laminae are characterized by filamentous microorganisms that lie parallel, to subparallel to the depositional surface (Figs 6A, 7A). Although most mats are monospecific, there are rare examples in which scattered specimens of other taxa may be present. There is relatively little porosity because the microorganisms are densely packed and the spaces between the filaments are typically filled with amorphous silica. In some laminae, hollow tubes (1-2 $\mu \mathrm{m}$ diameter) that were once occupied by the trichomes of the filamentous microorganisms, are the only porosity present.

U-laminae are characterized by composite pillars, up to 25 $\mu \mathrm{m}$ in diameter, that are formed of the merger of 5-10 subvertical to vertical silicified filamentous microorganisms (Figs 6A, 7A). Such mats, which are typically dominated by genera of Calothrix or Phormidium, commonly have a diverse biota. In many cases, Synechococcus sp. live as epiphytes on the surfaces of the vertical pillars. These laminae often have high porosity that is formed in the open spaces between the filaments, between the filament pillars, as well as the hollow tubes that were once occupied by the trichomes (16).

Frequently, the P-laminae and U-laminae form repetitive couplets (P-U couplets), with both laminae formed by the same filamentous microorganisms. Indeed, in many cases it is possible 

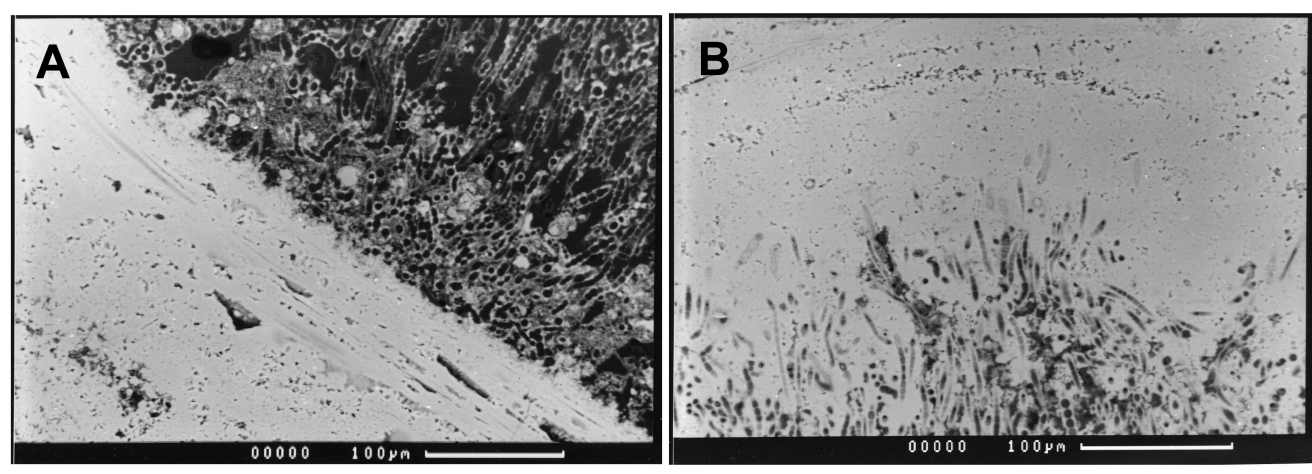

Figure 8. SEM images from a section of microstromatolite collected $5 \mathrm{~mm}$ below the sinter apron surface at the main vent at Krisuvik, Iceland. (A) sharp contact between an inorganic silica layer (bottom left) and the predominantly filamentous, verticallyaligned microbial layer dominated by Calothrix (top right) and (B) the gradational upper surface of the microbial layer. Note preferred vertical orientation of cyanobacteria towards the sediment-water interface and isolated filaments projecting into silica layer above. There is no continuum between cyanobacteria of one laye with those of an overlying microbial layer 100's of micrometers above. Modified from Konhauser et al. (42).

to find individual flat-lying filaments in the upper part of the P-laminae that, with growth, adopted an upright growth habit (Fig. 7B). The change in growth attitude is independent of taxa and probably reflects systematic temporal changes in the depositional environment (e.g. 53, 54).

For the stratiform stromatolites, as well as many other organosedimentary structures, the cyclic alternation between different laminae has been attributed to variations in growth patterns between the summer and winter months (e.g. 46, 51, 53-55). Caution must be attached to the exclusive acceptance of this idea because some filamentous microorganisms are known to change their growth attitude in response to daily phototactic controls (e.g. 17, 56, 57), whereas others such as Chloroflexus, respond to low levels of light rather than high light levels (55). Nevertheless, in most hot-spring systems, filamentous microorganisms tend to adopt an upright attitude during the summer that contrasts sharply with the prone attitude that is adopted during the winter months $(17,43)$. In some extremes, such as those in Iceland, the laminations consist of alternating layers, each $\sim 250 \mu \mathrm{m}$ thick, of filamentous populations of Calothrix and pure silica, devoid of any microbial component. The cyclical pattern arises from active cell growth during spring/summer when the microorganisms can keep pace with silicification (Fig. 8A), while during their natural slow growth phase in the dark autumn/winter months silicification exceeds the cyanobacterium's ability to grow upwards (Fig. 8B). When conditions once again become favorable for growth, recolonization of the solid silica surface by free-living cyanobacteria, from the overlying waters, occurs (46).

\section{Fabric Development}

The U-lamina and P-lamina commonly form couplets that are stacked one on top of the other. The compartment-like fabric produced by the combination of these microbial mats is a direct result of the growth dynamics of the constituent microorganisms. The rigidity of this fabric, that allows its long-term survival, is due to the early silicification of the microorganisms and subsequent enhancement by the amorphous silica that encrusts them. These processes take place irrespective of whether or not the microorganisms played an active role in their own silicification and encrustation. In some highly supersaturated spring waters, amorphous silica spheres may accumulate in the spaces between the pillars in the erect lamina.

Sinters formed of P-U couplets accrete vertically through time in direct response the continual seasonal cycles of growth. Thus, P-U couplets, with their primary porosity, become progressively buried by the growth of younger mats. Once below the surface of the discharge apron, the laminae are placed under the influence of subsurface waters that may, or may not, be related to the surface waters. Such waters will fill any porosity in the P- and U-laminae, with most being concentrated in the open compartments in the U-lamina (Fig. 9). In fact, most of these laminae are characterized by such high porosity and permeability that subsurface waters will easily pass through them. If the pore waters in the open compartments between the U-laminae are supersaturated with respect to amorphous silica, then precipitation will take place, whereby the previously silicified and encrusted filaments facilitate nucleation. Thus, isopachous amorphous silica cements should be found lining the walls of these compartments.

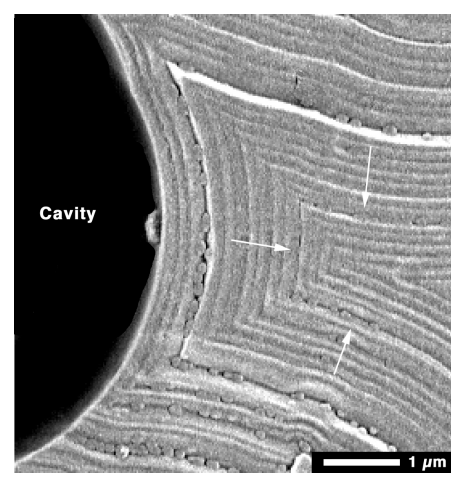

Figure 9. Example of isopachous amorphous silica cement in-filling the cavity of a stratiform stromatolite on the disform stromatolite on the dis-
charge apron on Waikite Geyser, Whakarewarewageothermal area. Cavity once occupied by a filamentous microbe. Etching by acidic steam shows morby acidic steam shows morphology of laminae in cement is inherited from the cavity walls and that amorphous silica formed through gradual accretion of thin laminae (arrows indicate growth direction).

Most amorphous silica in sinters appears featureless in thin section or on the scanning electron microscope, and it is therefore difficult to interpret their formation using techniques like those used to decipher the development of cements in carbonate rocks. Etching of the silica by acidic steam, which is common in the Waikite Geyser complex (Whakarewarewa Geothermal area, North Island, New Zealand) highlights its internal structures (58). Such etching, that can also be duplicated in the laboratory by using concentrated hydrofluoric acid, reveals laminations that record the accretion of silica in cavities that are akin to those found in the stratiform stromatolites. Analysis of those laminae shows amorphous silica commonly develops as isopachous cement that lines cavity walls (Fig. 9). Such cementation, that is indicative of precipitation in cavities that are filled with water, may eventually result in the complete occlusion of the cavity.

\section{SUMMARY}

Stratiform stromatolites have been used here to illustrate the processes that may control the development of siliceous sinter on the discharge apron of a hot spring or geyser. Despite the conclusions that microorganisms do not enhance the kinetics of silicification, and only marginally influence the magnitude of silicification, nonetheless, it is readily apparent that the early silicification of the microbial mats governs the development of the primary fabrics and ultimately, the distribution of later-stage diagenetic cement. The 'model' developed from examination of the stratiform stromatolite can be applied to virtually any other type of sinter biofacies found on discharge aprons. All sinters evolve through some combination of encrustation, replacement and cementation, with variations in the fabrics largely reflecting differences in the original growth attitudes of the constituent microorganisms. 
Gunnarsson, I. and Arnórsson, S., 2000. Amorphous silica solubility and the thermodynamic properties of $\mathrm{H}_{4} \mathrm{SiO}_{4}$ in the range of $0^{\circ}$ to $350^{\circ} \mathrm{C}$ at $\mathrm{P}$. Geochim. Cosmochim. Acta 64, 2295-2307.

2. Fournier, R.O. 1985. The behaviour of silica in hydrothermal solutions. In: Geology and Geochemistry of Epithermal Systems. Berger, B.R. and Bethke, P.M. (eds)

Crerar, D.A., Axtmann, E.V. and Axtmann, R.C. 1981. Growth and ripening of silica polymers in aqueous solutions. Geochim. Cosmochim. Acta 45, 1259-1266.

. Iler R K 1979 Chemistry of Silica. Wiley-Interscience, New York.

Rothbaum, H.P., Anderton, B.H., Harrison, R.F., Rohde, A.G. and Slatter, A. 1979. Effect of silica polymerization and $\mathrm{pH}$ on geothermal scaling Geothermics 8, 1-20.

6alter, M.R. 1976a. Geyserites of Yellowstone National Park: An example of abiogenic "stromatolites". In: Stromatolites. Developments in Sedimentology 20. Walter, M.R. (ed.) Elsevier,

Amsterdam, pp. 88-112. geysers and hot-spring vents, North Island, New Zealand. J. Sed. Res. 67, 88-104.

. Jones, B., Renaut, R.W. and Rosen, M.R. 2003. Silicified microorganisms in a geyser mound: the enigma of low-temperature cyanobacteria in a high-temperature setting.

9. Cady, S.L. and Farmer, J.D. 1996. Fossilization processes in siliceous thermal springs: Trends in preservation along thermal gradients. In: Evolution of Hydrothermal Ecosystems on Earth (and Mars?). Brock, G.R. and Goode, J.A. (eds). Wiley, Chichester, pp. 150-173.

10. Schultze-Lam, S., Ferris, F.G., Konhauser, K.O. and Wiese, R.G. 1995. In situ silicification of an Icelandic hot spring microbial mat: Implications for microfossil formation. Can. J. Earth Sci. 32, 2021-2026.

11. Konhauser, K.O. and Ferris, F.G. 1996. Diversity of iron and silica precipitation by microbial mats in hydrothermal waters, Iceland: Implications for Precambrian iron formations. Geology 24, 323-326.

2. Phoenix, V.R., Adams, D.G. and Konhauser, K.O. 2000. Cyanobacterial viability during hydrothermal biomineralization. Chem. Geol. 169, 329-338.

3. Jones, B., Renaut, R.W. and Rosen, M.R. 2000. Stromatolites forming in acidic hot-spring waters. Palaios, 15 , 450-475.

4. Knoll, A.H., Strother, P.K. and Rossi, S. 1988. Distribution and diagenesis of microfossils from the Lower Proterozoic Duck Creek Dolomite, Western Australia. Precamb. Res., 38, $257-279$

15. Bartley, J.K. 1996. Actualistic taphonomy of cyanobacteria: Implications for the Precambrian fossil record. Palaios 11, 571-586.

16. Jones, B., Renaut, R.W. and Rosen, M.R. 1998. Microbial biofacies in hot-spring sinters: A model based on Ohaaki Pool, North Island, New Zealand. J. Sed. Res. 68, 413-434.

17. Walter, M.R., Bauld, J. and Brock, T.D. 1972. Siliceous algal and bacterial stromatolites in hot

spring and geyser effluents of Yellowstone National Park. Science 178, 402-405.
18. Ferris, F.G., Beveridge, T.J. and Fyfe, W.S. 1986. Iron-silica crystallite nucleation by bacteria in a geothermal sediment. Nature 320,609-611.

19. Mountain, B.W., Benning, L.G. and Boerema, J.A. 2003. Experimental studies on New Zealand hot spring sinters: Rates of growth and textural development. Can. J. Earth Sci. 40, $1643-1667$

20. Oehler, J.H. 1976. Experimental studies in Precambrian paleontology: Structural and chemi$\mathrm{cal}$ changes in blue-green algae during simulated fossilization in synthetic chert. Geol. Soc. Am. Bull. 87, 117-129.

21. Francis, S., Margulis, L. and Barghoorn, E.S. 1978. On the experimental silicification of miOn the time of appearance of eukaryotic organisms in the fossil record. Precamb. Res 6, 65-100.

22. Westall, F., Boni, L. and Guerzoni, E. 1995. The experimental silicification of microorganisms. Palaeontology 38, 495-528.

23. Westall, F. 1997. The influence of cell wall composition on the fossilization of bacteria and the implications for the search for early life forms. In: Astronomical and Biochemical Origins and the Search for Life in the Universe. Cosmovici, C., Bowyer, S. and Werthimer, D. (eds). Editori Compositrici, Bologna, pp. $491-504$.

24. Toporski, J.K.W., Steele, A., Westall, F., Thomas-Keprta, K.L. and McKay, D.S. 2002 The simulated silicification of bacteria - New clues to the modes and timing of bacterial preservation and implications for the search for extraterrestrial microfossils. Astro-

25. Fein, J.B., Scott, S. and Rivera, N. 2002. The effect of Fe on Si adsorption by Bacillus subtilis cell walls: Insights into non-metabolic bacterial precipitation of silicate minerals. Chem. Geol. cell walls: Insi

26. Yee, N., Phoenix, V.R., Konhauser, K.O., Benning, L.G. and Ferris, F.G. 2003. The effect of cyanobacteria on silica precipitation at neutral $\mathrm{pH}$ : Implications for bacterial silicification in cyanobacteria on silica precipitation at neutral pH:

27. Urrutia, M.M. and Beveridge, T.J. 1993. Mechanism of silicate binding to the bacterial cell wall in Bacillus subtilis. J. Bacteriol. 175, 1936-1945.

28. Heaney, PJ and Yates, D.M. 1998 . Solution chemistry of wood silicification. Geol. Soc. Am. Annu. Meet., Abstr. Program 30, A-375.

29. Benning, L.G., Phoenix, V., Yee, N. and Konhauser, K.O. 2003. The dynamics of cyanobacteral silicification: An infrared micro-spectroscopic investigation. Geochim Cosmochim. Acta $68,743-757$.

30. Leo, R.F. and Barghoorn, E.S. 1976. Silicification of wood. Bot. Mus. Leaf.., Harv. Univ. 25, 1-29.

1. Phoenix, V.R., Martinez R.E., Konhauser, K.O. and Ferris F. G. 2002. Characterization and implications of the cell surface reactivity of the cyanobacteria Calothrix sp. App. Environ.

Microbiol. 68, 4827-4834. minium under physiological and natural conditions. J. Am. Chem. Soc. 119, 8852-8856.

Warren, L.A. and Ferris, F.G. 1998. Continuum between sorption and precipitation of $\mathrm{Fe}$ (III) on microbial surfaces. Environ. Sci. Tech. 32, 2331-233

4. Phoenix, V.R., Konhauser, K.O. and F.G. Ferris. 2003. Experimental study of iron and silica immobilization by bacteria in mixed Fe-Si systems: Implications for microbial silicification in

hot-springs. Can. J. Earth Sci. 40, 1669-1678.
5. Konhauser, K.O., Fyfe, W.S., Ferris, F.G. and Beveridge, T.J. 1993. Metal sorption and mineral precipitation by bacteria in two Amazonian river systems: Rio Solimões and Rio Negro. Geology 21, 1103-1106.

6. Swelund, P.J. and Webster, J.G. 1999. Adsorption and polymerization of silicic acid on ferrihydrite, and its effect on arsenic adsorption. Water Res. 33, 3414-3422.

37. Davis, C.C., Chen, H-W. and Edwards, M. 2002. Modelling silica sorption to iron hydroxide. Environ. Sci. Tech. 36, 582-587.

38. Jones, B., Konhauser, K., Renaut, R.W. and Wheeler, R. Microbial silicification in Iodine Pool, Waimangu geothermal area, North Island, New Zealand: Implications for recognitio and identification of ancient silicified microbes. Geological Society of London. (In press).

39. Renaut, R.W., Jones, B. and Tiercelin, J.J. 1998. Rapid in situ silicification of microorganism at Loburu hot springs, Lake Bogoria, Kenya Rift Valley. Sedimentology 45, 1083-1103.

40. Lowe, D.R. and Braunstein, D. 2003. Microstructure of high-temperature $\left(>73^{\circ} \mathrm{C}\right)$ siliceous sinter deposited around hot springs and geysers, Yellowstone National Park: The role of biological and abiological processes in sedimentation. Can. J. Earth Sci. 40, 1611-1642.

41. Jones, B. and Renaut, R.W. 2003a. Hot spring and geyser sinters - the integrated product of precipitation, replacement, and deposition. Can. J. Earth Sci. 40, 1549-1569.

42. Konhauser, K.O., Jones, B., Reysenbach, A.-L., and Renaut, R.W., 2003. Hot spring sinters: Keys to understanding Earth's earliest life forms. Can. J. Earth Sci. 40, 1713-1724. Developments in Sedimentology 20. Walter, M.R. (ed.). Elsevier, Amsterdam, pp. 489-498.
44. Cassie, V. and Cooper, R.C. 1989. Algae of New Zealand thermal areas. Bibliotheca Phycol. $78,1-159$

45. Jones, B., Renaut, R.W. and Rosen, M.R. 2001. Taphonomy of silicified filamentous microorganisms in modern geothermal sinters - implications for identification. Palaios, 16, 580-592. Konhauser, K.O., Phoenix, V.R., Bottrell, S.H., Adams, D.G. and Head, I.M. 2001. Microbialsilica interactions in modern hot spring sinter: Possible analogues for Precambrian siliceous

stromatolites. Sedimentology 48, 415-435.
47. Jones, B., Renaut, R.W. and Rosen, M.R. 1999b. Role of fungi in the formation of siliceous coated grains, Waiotapu geothermal area, North Island, New Zealand. Palaios 14, 475-492.

48. Castenholz, R.W. 1978. The biogeography of hot spring algae through enrichment cultures. Mitt. Internat. Verein. Limnol., 21, 296-315.

49. Ward, D.M., Weller, R., Shiea, J., Castenholz, R.W. and Cohen, Y. 1989. Hot spring microbial mats: Anoxygenic and oxygenic mats of possible evolutionary significance. In: Microbial Mats: Physiological Ecology of Benthic Microbial Communities. Cohen, Y. and Rosenberg,

E. (eds). American Society for Microbiology, Washington, D.C., pp. 3-13.
50. Jones, B., Renaut, R.W. and Rosen, M.R. 1997. Biogenicity of silica precipitation around Jones, B., Renaut, R.W. and Rosen, M.R. 1997. Biogenicity of silica precipitation
geysers and hot-spring vents, North Island, New Zealand. J. Sed. Res. 67, 88-104

51. Reyaut, R.W. Jones, B and Rosen, M.R. 1996. Primary silica oncoids from Orakeikorako hot springs, North Island, New Zealand. Palaios 11, 446-458.

52. Jones, B. and Renaut, R.W. 1997. Formation of silica oncoids around geysers and hot springs at El Tatio, northern Chile. Sedimentology 44, 287-304.

3. Jones, B., Renaut, R.W. and Rosen, M.R. 1999a. Actively growing siliceous oncoids in the Waiotapu geothermal area, North Island, New Zealand. J. Geol. Soc. London 156, 89-103.

Chafetz, H.S., Utech, N.M. and Fitzmaurice, S.P. 1991. Differences in the $\delta^{18} \mathrm{O}$ and $\delta^{13} \mathrm{C}$ signatures of seasonal laminae comprising travertine stromatolites. J. Sediment. Petrol. 61, 1015 1028 .

55. Monty, C.L.V. 1976. The origin and development of cryptalgal fabrics. In: Stromatolites, Developments in Sedimentology 20. Walter, M.R. (ed.). Elsevier, Amsterdam, pp. 193-250. . Monty, C.L.V. 1967. Distribution and structure of recent stromatolitic algal mats, eastern Andros Island, Bahamas. Soc. Géol. de Belgique Ann. 96, 585-624.

7. Golubic, S. and Focke, J.W. 1978. Phormidium hendersonii: Identity and significance of a modern stromatolite building micro-organism. J. Sed. Pet. 48, 761-764

8. Jones, B., and Renaut, R.W. 2003b. Petrography and genesis of geyserite from the Whakarewarewa and Orakeikorako geothermal areas, North Island, New Zealand. Can. J. Earth Sc $40,1585-1610$

Kurt Konhauser is a Canadian Research Chair in Geomicrobiology at the University of Alberta. He is also Editor-in-Chief of Geobiology. His research interests include the role of bacteria in mineral precipitation in both modern and ancient environments. His address: Canada Research Chair in Geomicrobiology, Department of Earth and Atmospheric Sciences, University of Alberta, Edmonton, Alberta, T6G 2E3, Canada. kurtk@ualberta.ca

Brian Jones is a professor of geology and the C.R. Stelck Chair in Petroleum Geology at the University of Alberta. He is the Editor-in-Chief for the Canadian Journal of Earth Sciences. His research interests include hot spring deposits and the sedimentology and diagenesis of modern and ancient carbonate deposits. His address: Department of Earth and Atmospheric Sciences, University, of Alberta, Edmonton, Alberta, T6G 2E3, Canada.

brian.jones@ualberta.ca

Vernon Phoenix is a Postdoctoral Fellow at the University of Guelph. His research interests include the potentiometric properties of bacterial surfaces and UV screening mechanisms of ancient life forms. His address: Department of Microbiology, University of Guelph, Guelph, Ontario, N1G 2W1 Canada. vphoenix@uoguelph.ca

Grant Ferris is a professor of geology at the University of Toronto. His research interests are the surface physico-chemical properties of bacteria and iron oxide minerals, microbial silicification and microbe-iron cycling. His address: Department of Geology, University of Toronto, Toronto, Ontario, M5S 3B1, Canada. grant.ferris@utoronto.ca

Robin Renaut is a professor of geology at the University of Saskatchewan. His research interests are in geothermal deposits, the sedimentology and hydrochemistry of saline lakes, and the geology of the Kenya Rift. His address: Department of Geological Sciences, University of Saskatchewan, Saskatoon, Saskatchewan, S7N 5E2, Canada. robin.renaut@usask.ca 